\title{
Responsiveness of endometrial genes Connexin26, Connexin43, C3 and clusterin to primary estrogen, selective estrogen receptor modulators, phyto- and xenoestrogens
}

\author{
S Heikaus, E Winterhager, O Traub ${ }^{1}$ and R Grümmer \\ Institute of Anatomy, University Hospital Essen, D-45122 Essen, Germany \\ ${ }^{1}$ Institute of Genetics, University of Bonn, 53117 Bonn, Germany \\ (Requests for offprints should be addressed to R Grümmer; Email: ruth.gruemmer@uni-essen.de)
}

\begin{abstract}
Phytohormones and chemical compounds revealing estrogenic effects are of increasing interest for their possible influence on the physiology of the reproductive tract. The gap junction connexin $(\mathrm{Cx})$ genes Cx26 and Cx43, the plasma glycoprotein clusterin gene and the complement C3 gene are highly regulated by estrogen in rat endometrium. To test the value of these genes as markers for estrogenic responsiveness we analyzed the effects of estradiol, diethylstilbestrol, the selective estrogen receptor modulators (SERMs) raloxifene and tamoxifen, the phytoestrogens genistein and daidzein, and the industrial compounds DDT (1,1,1-trichloro-2-(2-chlorophenyl)-2-(4-chlorophenyl) ethane) and polychlorinated biphenyl (PCB) on the transcription of these genes in rat endometrium in vivo. Enhancement of Cx26 and decrease of clusterin transcripts expression by estradiol was observed at $0.03 \mu \mathrm{g} / 250 \mathrm{~g}$ body weight (BW), and induction of C3 expression was observed at $0.05 \mu \mathrm{g} / 250 \mathrm{~g} \mathrm{BW}$. A comparable effect was obtained by a tenfold higher concentration of diethylstilbestrol. Tamoxifen had a regulatory effect on this set of genes at about a 300 -fold higher concentration, while raloxifen revealed much weaker estrogenic activity. No effect on $\mathrm{C} \times 43$ transcripts was observed with any of the compounds at the concentrations used. An effect of genistein was observed only on Cx26 expression, while PCB decreased clusterin transcripts. These results show that $\mathrm{C} \times 26, \mathrm{C} 3$ and clusterin reveal a comparable sensitivity to estrogens and SERMs. With respect to the phytoestrogen genistein, however, Cx26 seems to be the most sensitive gene. The analysis of clusters of estrogen-sensitive endometrial genes could help to identify estrogenic substances, assess their potency, and elucidate their mechanism of action.
\end{abstract}

Journal of Molecular Endocrinology (2002) 29, 239-249

\section{Introduction}

Pharmaceutical compounds as well as environmental and dietary substances revealing estrogenic effects are of increasing interest because of their potential biological impact on human health. Exposure to such substances has been associated with an increased incidence of hormone-dependent tumorigenesis like testicular, endometrial and breast cancer (Davis et al. 1993, Cotton 1994, Safe 1995, Thierfelder et al. 1995), disorders of the male reproductive tract (Sharpe \& Skakkebaek 1993, Cooper \& Kavlock 1997), and interference with reproductive physiology (Auger 1995, Safe 1995,
Strauss et al. 1998a). A remarkable diversity of naturally occurring and synthetic compounds has been shown to mimic the biological effects of $17 \beta$-estradiol. This includes synthetic estrogens such as tamoxifen and raloxifene, which have been developed as antiestrogens for the therapy of breast cancer (Nass et al. 1998, Overmoyer 1999), phytoestrogens from plant origin (Markiewicz et al. 1993) as well as pesticides and industrial chemicals (Schaefer et al. 1996).

Although many of these substances are known to bind to the estrogen receptor (Kuiper et al. 1997), there is little information about the molecular mechanisms and the biological potency of these 
compounds. In vitro estrogen receptor binding assays do not provide information about the physiological activity of the substances tested (Hopert et al. 1998). Receptor binding studies neither discriminate between estrogenic and antiestrogenic effects nor do they allow for the fact that some non-estrogenic chemicals are metabolized in vivo to compounds that are estrogenic (Jorgensen et al. 1998). Thus there is a need for biological models to characterize the hormonal activity of substances which reveal estrogenic effects or act as endocrine disruptors to elucidate the systemic mechanisms of their action. Several in vitro assays have been developed to assess the estrogenlike activity of individual compounds or natural mixtures (Zacharewski 1997), but they all show limitations as only isolated aspects can be investigated.

The uterus is a classical target organ for estrogenic action. The widely used uterotropic assay determines the increase in uterine wet weight (Lan \& Katzenellenbogen 1976); however, in this assay different effects leading to this increase in weight cannot be discriminated. Meanwhile, it has been shown that compounds revealing estrogenic effects may lead to only a partial estrogenic transformation. In the past years a large number of genes has been identified which are regulated in the endometrium and can be used as marker genes for estrogenicity. It has been shown that estrogen enhances transcription of the complement C3 gene (Sundstrom et al. 1989, Hopert et al. 1998, Diel et al. 2000) but inhibits expression of the clusterin gene (Wunsche et al. 1998, Diel et al. 2000) and thus reveals selective regulatory effects on endometrial genes.

Recently, we demonstrated that the gap junction protein connexin $(\mathrm{Cx}) 26$ is sensitively regulated by estrogen in rat endometrium (Grümmer et al. 1994, 1999) and may serve as a marker gene to identify estrogenic effects in the uterus. Since the differences in signaling pathways of estrogens, selective estrogen modulators (SERMs) and substances known as endocrine disruptors are still unknown, a screening system for a set of marker genes is needed to evaluate the estrogenic effects in detail. In order to evaluate genes as sensitive indicators for estrogenic effects we have compared the regulation properties of a set of endometrial genes - Cx26, Cx43, complement C3, and clusterin. These estrogen-sensitive genes have been chosen to evaluate their functional significance as marker genes for screening the estrogenic potential of the estrogen agonist diethylstilbestrol (DES), the SERMs tamoxifen and raloxifen, as well as the phytoestrogens genistein and daidzein, and the xenoestrogens DDT (1,1,1-trichloro-2-(2chlorophenyl)-2-(4-chlorophenyl) ethane) and polychlorinated biphenyl (PCB). We demonstrate that Cx26, clusterin and C3 show a similar responsiveness to estrogen and to SERMs, whereas with regard to the phytoestrogen genistein Cx26 seems to be the most sensitive. Thus this endometrial gene cluster is highly suited for the investigation of the biological potential of natural and synthetic estrogens and for the evaluation of the signal cascades involved.

\section{Materials and methods}

\section{Animal care}

Adult female Sprague-Dawley rats were housedunder defined conditions with a temperature of $22 \pm 1{ }^{\circ} \mathrm{C}$, an atmospheric humidity of $55 \pm 10 \%$, and a 12-h darkness:12-h light cycle. They were fed standard pellet food and water was provided ad libitum. All animal experiments were approved by the institutional animal care committee.

\section{Treatment and compounds}

Rats of $250 \mathrm{~g}$ body weight were ovariectomized and kept for 14 days before treatment to allow the endogenous ovarian hormone levels to decline. A single injection of the following compounds was administered subcutaneously in $200 \mu \mathrm{l}$ sesame oil: $17 \beta$-estradiol $\left(\mathrm{E}_{2} ; 0.01,0.03,0.05,0.08 \mu \mathrm{g} / \mathrm{rat}\right)$, DES $(0 \cdot 05,0 \cdot 1,0 \cdot 3,0 \cdot 5,1,10 \mu \mathrm{g} / \mathrm{rat})$, tamoxifen $(1,10,100 \mu \mathrm{g} / \mathrm{rat})$, genistein and daidzein $(2 \cdot 5 \mathrm{mg} /$ rat) were obtained from Sigma (Deisenhofen, Germany), 1,1,1-trichloro-2-(2-chlorophenyl)-2-(4chlorophenyl) ethane (o,p'-DDT; $2.5 \mathrm{mg} / \mathrm{rat})$ was obtained from the Institute of Organic Industrial Chemistry (Warsaw, Poland), polychlorinated biphenyl (PCB; $2.5 \mathrm{mg} / \mathrm{rat}$ ) was obtained from Environmental Solutions Inc. (Longwood, USA), Raloxifen (1, $10 \mu \mathrm{g} / \mathrm{rat}$ ) was kindly provided by Schering AG (Berlin, Germany), and ICI 182,780 (ICI; $0.5 \mathrm{mg} / \mathrm{rat}$ ) by A Wakeling (Zeneca Pharmaceuticals, UK). $\mathrm{E}_{2}$, DES, tamoxifen, ICI, genistein, and $\mathrm{PCB}$ were dissolved in a 1:1 mixture of ethanol and benzylbenzoate, raloxifen and DDT were 
dissolved in ethanol, and daidzein was dissolved in DMSO. Rats were killed $24 \mathrm{~h}$ after injection of compounds. Controls were given an equal volume of vehicle only. Three animals were used for each experiment.

\section{Tissue collection}

Animals were killed by ether and uteri were removed. Small pieces of the uteri were frozen in liquid nitrogen for subsequent histochemical analysis, the remaining uteri were opened longitudinally on an ice-cold glass plate and the endometrium was carefully scraped off. Histological examination of the removed endometrium revealed no contamination with myometrial tissue (data not shown). The endometrial samples of the three rats per experimental approach were pooled, frozen in liquid nitrogen, and stored at $-80^{\circ} \mathrm{C}$.

\section{Northern blot analysis}

Total RNA was extracted from endometrial tissue using the RNAeasy midi kit (Qiagen, Hilden, Germany). Five micrograms (as estimated from optical absorbance mearurements at $260 \mathrm{~nm}$ ) were electrophoresed on a denaturing agaroseformaldehyde gel and blotted onto nylon membranes (Hybond-M, Amersham-Bucher $\mathrm{GmbH}$ ). cDNA probes were random-prime labeled with $\left[{ }^{32} \mathrm{P}\right] \mathrm{dCTP}$ and hybridized with the RNA blots overnight at $42{ }^{\circ} \mathrm{C}$ in a solution containing $55 \%$ deionized formamide, $1 \mathrm{M} \mathrm{NaCl}, 1 \%$ sodium dodecyl sulfate (SDS), 10\% dextran sulfate, and $100 \mu \mathrm{g} / \mathrm{ml}$ salmon sperm DNA. cDNAs of the following genes were used for hybridization: rat Cx26 (Zhang \& Nicholson 1989), rat Cx43 (Beyer et al. 1987), rat complement C3 (Sundstrom et al. 1989), and rat clusterin (Guenette et al. 1994). Blots were washed at $60{ }^{\circ} \mathrm{C}$ in $1 \times \mathrm{SSC}, 0 \cdot 1 \% \mathrm{SDS}$ for $1 \mathrm{~h}$, in $0.5 \times \mathrm{SSC}$, $0 \cdot 1 \% \mathrm{SDS}$ for $30 \mathrm{~min}$, and in $0 \cdot 2 \times \mathrm{SSC}, 0 \cdot 1 \% \mathrm{SDS}$ for $30 \mathrm{~min}$. Exposure to Kodak XAR-5 films took place at $-80^{\circ} \mathrm{C}$ with intensifying screens. After exposure, each blot was re-hybridized with a rat actin-specific cDNA probe (Reuss et al. 1996) using the same conditions of hybridization.

In each experiment the endometrium of 3 animals was pooled. Signals detected by autoradiography were quantified by densitometry. Densitometric values for gene expression were calculated relative to the $\beta$-actin level of the corresponding lane for possible differences in RNA loading.

\section{Immunohistochemistry}

Immunohistochemical staining was performed on cryostat sections $(4-6 \mu \mathrm{m})$ as described previously (Winterhager et al. 1991) using affinity purified rabbit antibodies $(1 \mu \mathrm{g} / \mathrm{ml})$ to Cx26 from mouse liver gap junctions (Traub et al. 1989) and to a synthetic peptide representing the C-terminal 22 amino acids of rat Cx43 (Traub et al. 1992). For positive controls, rat heart ( $\mathrm{Cx} 43)$ and liver (Cx26) were tested. For controls, rabbit preimmune serum was used instead of the primary antibody. Photographs were taken with an Axiophot microscope (Zeiss) equipped for epifluorescence.

\section{Results}

\section{Regulation of Cx26, Cx43, C3 and clusterin gene expression by estrogen and DES}

$\mathrm{E}_{2}$ was applied to ovariectomized rats as a single injection at concentrations ranging from 0.01 to $0.08 \mu \mathrm{g} /$ rat. mRNA levels of Cx26, Cx43, C3 and clusterin genes were analyzed in the endometrium $24 \mathrm{~h}$ after treatment. Cx26 gene expression was already induced at an $\mathrm{E}_{2}$ concentration as low as $0.03 \mu \mathrm{g} / \mathrm{rat}$, and complement C3 gene expression was induced at $0.05 \mu \mathrm{g} \mathrm{E} \mathrm{E}_{2} /$ rat (Fig. 1). The amount of transcripts of both genes increased in a genedose-dependent manner. Using the same concentrations, however, no increase in Cx43 mRNA could be observed. In former studies, an increase in $\mathrm{Cx} 43$ gene expression was induced by $\mathrm{E}_{2}$ levels from $0 \cdot 1 \mu \mathrm{g} /$ rat upwards (Grümmer et al. 1999). Clusterin gene expression which is known to be suppressed by $\mathrm{E}_{2}$ was decreased from a concentration of $0.03 \mu \mathrm{g} /$ rat upwards (Fig. 1), indicating a similar sensitivity to $\mathrm{E}_{2}$ compared with $\mathrm{C} 3$ and $\mathrm{Cx} 26$.

The strong estrogen agonist DES revealed a similar effect on endometrial gene expression; however, compared with $\mathrm{E}_{2}$, DES had to be applied in about a tenfold higher concentration $(0 \cdot 3 \mu \mathrm{g} / \mathrm{rat})$ to induce comparable levels of $\mathrm{Cx} 26$ and $\mathrm{C} 3$ transcripts or to inhibit clusterin mRNA. No effect on Cx43 gene expression was observed after application of DES at concentrations of 1 and $10 \mu \mathrm{g} /$ rat respectively (Fig. 1). It has already been shown that induction of connexin genes by $\mathrm{E}_{2}$ is mediated via the estrogen receptor (Grümmer et al. 1999). Also, the action of DES on Cx26 and C3 gene induction and the suppression of clusterin is mediated by the estrogen receptor since the effect of DES on all endometrial genes tested is abolished 


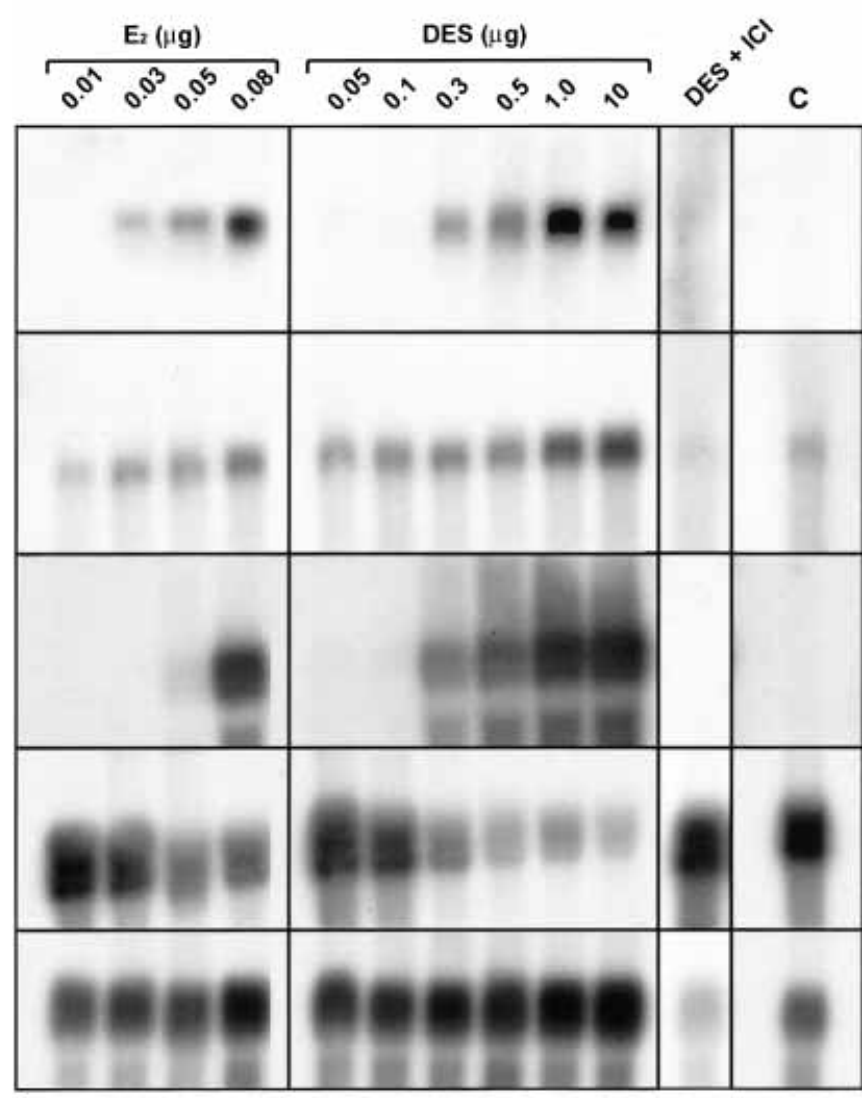

Cx26

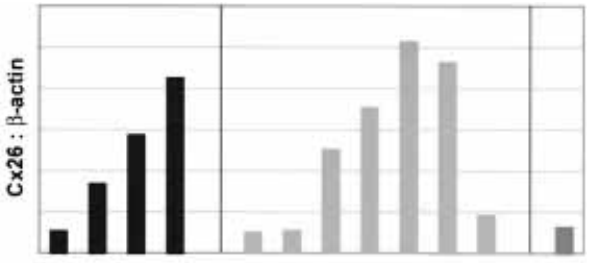

Cx43

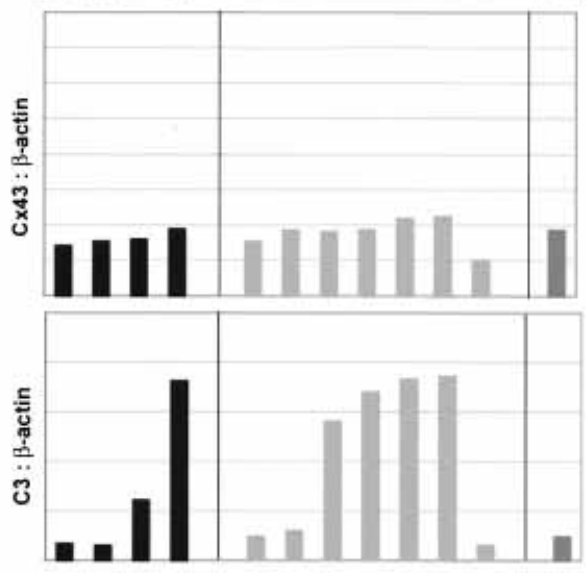

C3

clusterin

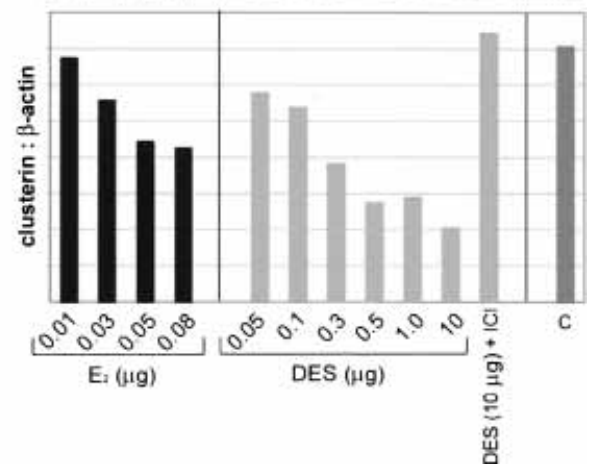

Figure 1 Northern blot (left) and corresponding densitometric evaluation (right) of endometrial RNA $24 \mathrm{~h}$ after injection of $E_{2}$ or DES. Induction of Cx26 and C3 gene expression was observed from a concentration of $0.03 \mu \mathrm{g} / \mathrm{rat}$ and $0.5 \mu \mathrm{g} / \mathrm{rat}$, respectively, and upwards, while there was no increase in Cx43 transcripts. Clusterin gene expression was decreased at an $E_{2}$ concentration as low as $0.03 \mu \mathrm{g} / \mathrm{rat}$. DES had to be applied in a tenfold higher concentration compared with $\mathrm{E}_{2}$ to achieve a similar effect on endometrial gene expression, which could be inhibited by simultaneous injection of $0.5 \mathrm{mg} \mathrm{ICI} 182,780$ (ICI). Controls (C) were treated with vehicle only.

by simultaneous application of $0.5 \mathrm{mg}$ of the antiestrogen ICI 182,780 (Fig. 1).

Expression and localization of connexin proteins after estrogen and DES treatment was investigated by immunohistochemistry. The corresponding Cx26 protein was detected $24 \mathrm{~h}$ after application of $0.08 \mu \mathrm{g}$ $\mathrm{E}_{2}$ (Fig. 2b) or $1 \mu \mathrm{g}$ DES (Fig. 2d). Application of lower amounts of $\mathrm{E}_{2}$ and DES respectively, which increased mRNA levels, did not lead to detectable levels of Cx26 protein (Fig. 2a,c). Cx43 protein was

Figure 2 Immunohistochemical localization of Cx26 and Cx43 in endometrium of ovariectomized rats treated with estrogen agonists and SERMs, respectively. While no Cx26 protein is detected $24 \mathrm{~h}$ after application of $0.03 \mu \mathrm{g} \mathrm{E}_{2} / \mathrm{rat}$ (a) and $0.03 \mu \mathrm{g} \mathrm{DES} / \mathrm{rat}(\mathrm{c})$, a clear punctate staining for $\mathrm{C} \times 26$ can be seen in the epithelium (E) of rats treated with $0.08 \mu \mathrm{g} E_{2}$ (b) or $1 \mu \mathrm{g}$ DES (d) respectively. Cx43 protein is expressed in the stromal compartment (S) of untreated ovariectomized rats $(e)$ and shows no change in strength of reaction when rats were treated with up to $0.1 \mu g E_{2}(f)$. While application of $100 \mu \mathrm{g}$ tamoxifen leads to a distinct punctate reaction for $\mathrm{C} \times 26$ antigen in the epithelial cells $(\mathrm{g})$, no staining can be observed $24 \mathrm{~h}$ after injection of $100 \mu \mathrm{g}$ raloxifen (h). Bar in a and $c-h=50 \mu \mathrm{m}$, in $b=30 \mu \mathrm{m}$. 

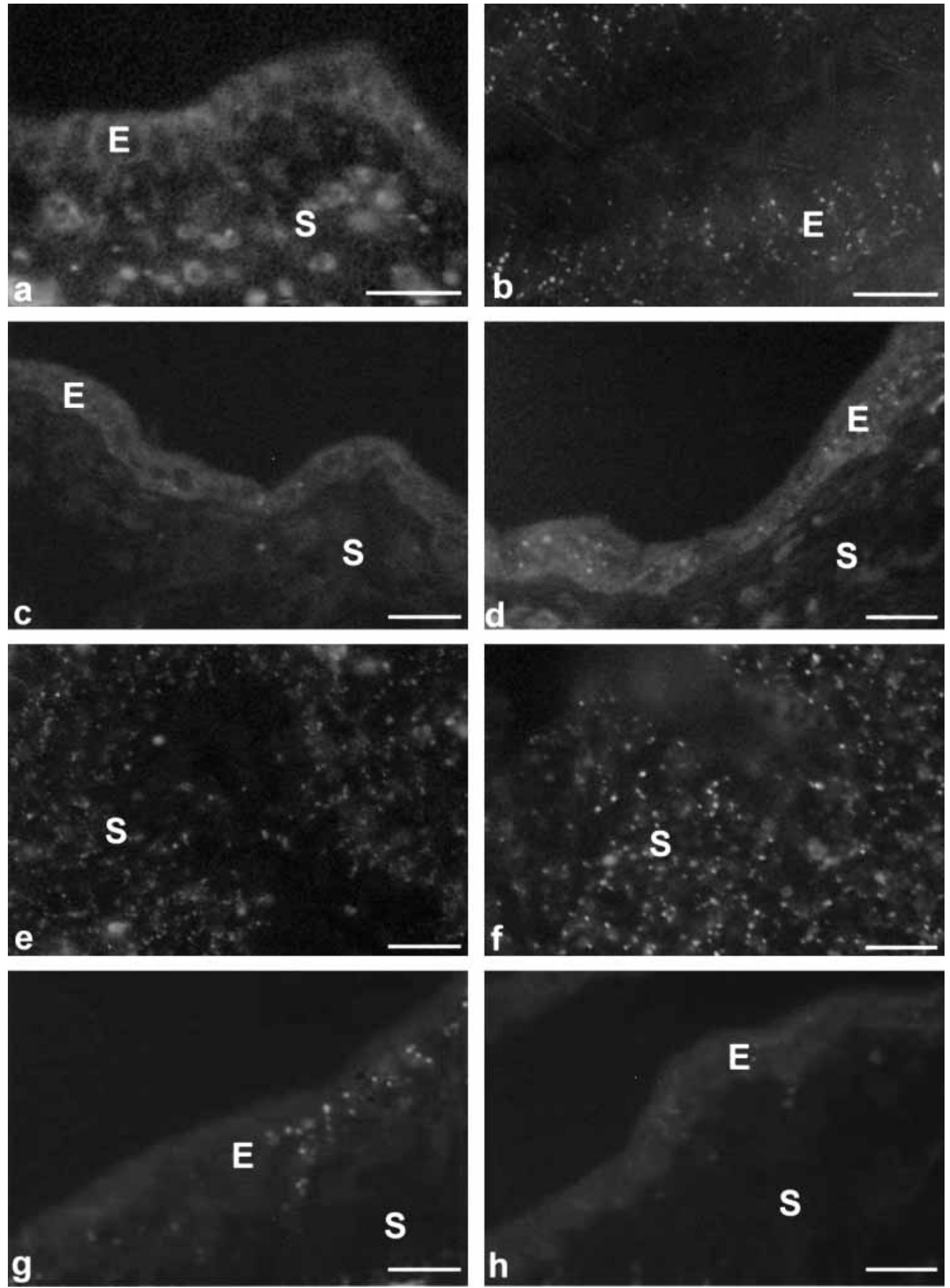

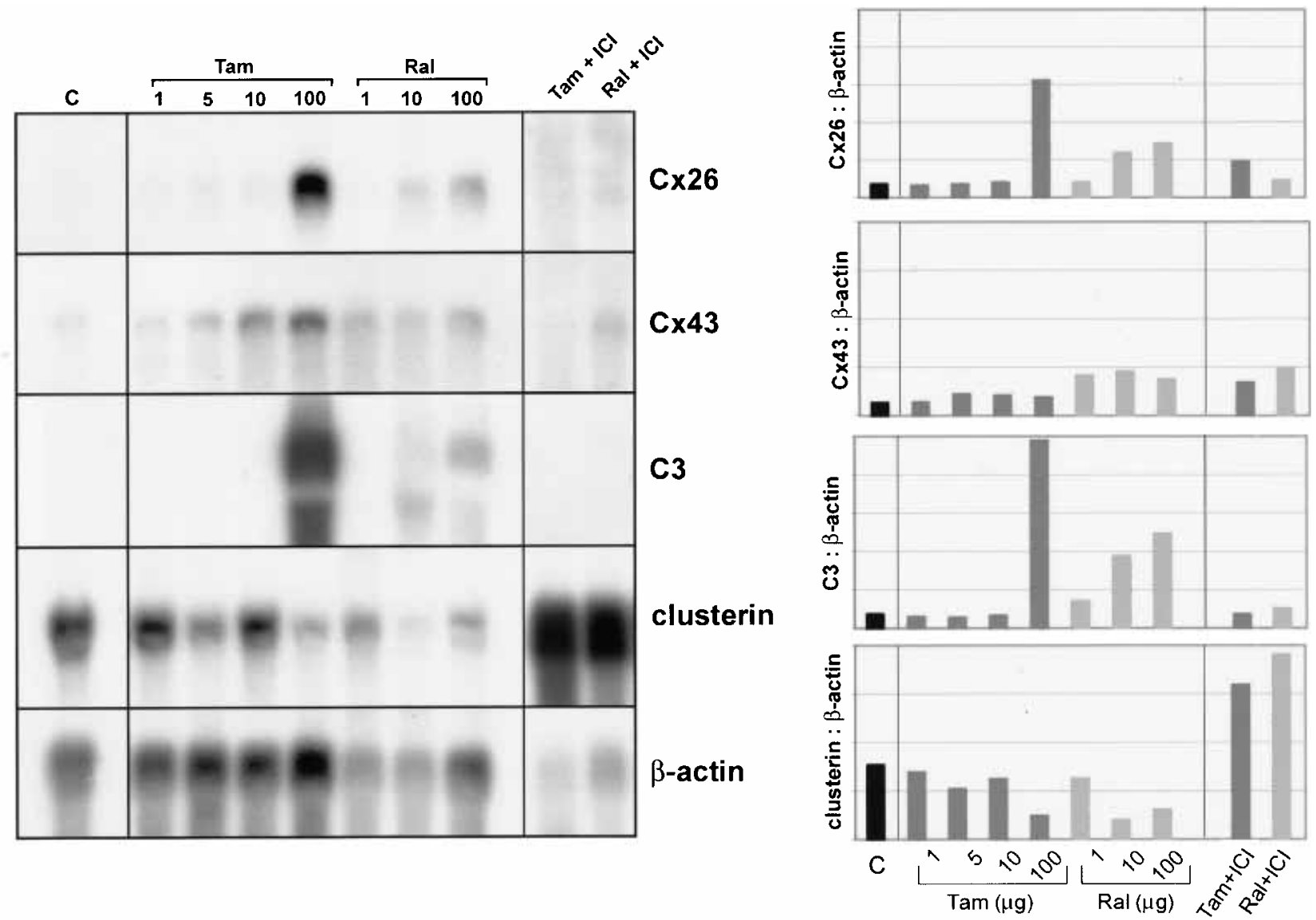

Figure 3 Northern blot (left) and corresponding densitometric evaluation (right) of endometrial RNA $24 \mathrm{~h}$ after application of tamoxifen (Tam) or raloxifen (Ral) to ovariectomized rats. At a concentration of $100 \mu \mathrm{g} / \mathrm{rat}$ both compounds reveal a clear inductive effect on Cx26 and C3 gene expression but this treatment leads to a decrease in clusterin transcripts, raloxifen showing a lower estrogenic effect than tamoxifen. These effects are inhibited by simultaneous application of $0.5 \mathrm{mg} \mathrm{ICI} \mathrm{182,780} \mathrm{(ICl),} \mathrm{which} \mathrm{even} \mathrm{causes} \mathrm{an} \mathrm{enhancement} \mathrm{of} \mathrm{clusterin} \mathrm{transcript}$ expression. Controls $(C)$ were treated with vehicle only.

expressed in the endometrial stromal compartment of untreated ovariectomized rats independent of hormonal treatment (Fig. 2e); however, no obvious difference in immunolabeling was seen compared with rats treated with $0 \cdot 1 \mu \mathrm{g} \mathrm{E}_{2}$ (Fig. 2f).

\section{Regulation by tamoxifen and raloxifen}

The effect of the selective estrogen receptor modulators (SERMs) tamoxifen and raloxifen on endometrial gene expression has also been analyzed $24 \mathrm{~h}$ after a single subcutaneous injection of these SERMs at different concentrations. Both compounds were able to induce $\mathrm{Cx} 26$ and $\mathrm{C} 3$ gene expression and to decrease the amount of clusterin transcripts; however, much higher concentrations were needed compared with estrogen and DES (Fig. 3). An inductive effect on Cx26 and C3 gene expression and a decrease in clusterin transcripts could be achieved by application of $100 \mu \mathrm{g}$ tamoxifen/rat. In comparison with tamoxifen, the same concentration of raloxifen acts only as a weak agonist on endometrial gene expression. This difference in agonistic action of the two SERMs could be confirmed by immunohistochemistry for Cx26 protein expression. While there was a distinct punctate reaction for $\mathrm{Cx} 26$ antigen in the endometrial epithelium $24 \mathrm{~h}$ after injection of $100 \mu \mathrm{g}$ tamoxifen (Fig. $2 \mathrm{~g}$ ), no protein expression was observed after application of the same amount of raloxifen (Fig. 2 h). No regulatory effect of either SERM could be seen on Cx43 gene transcription. 

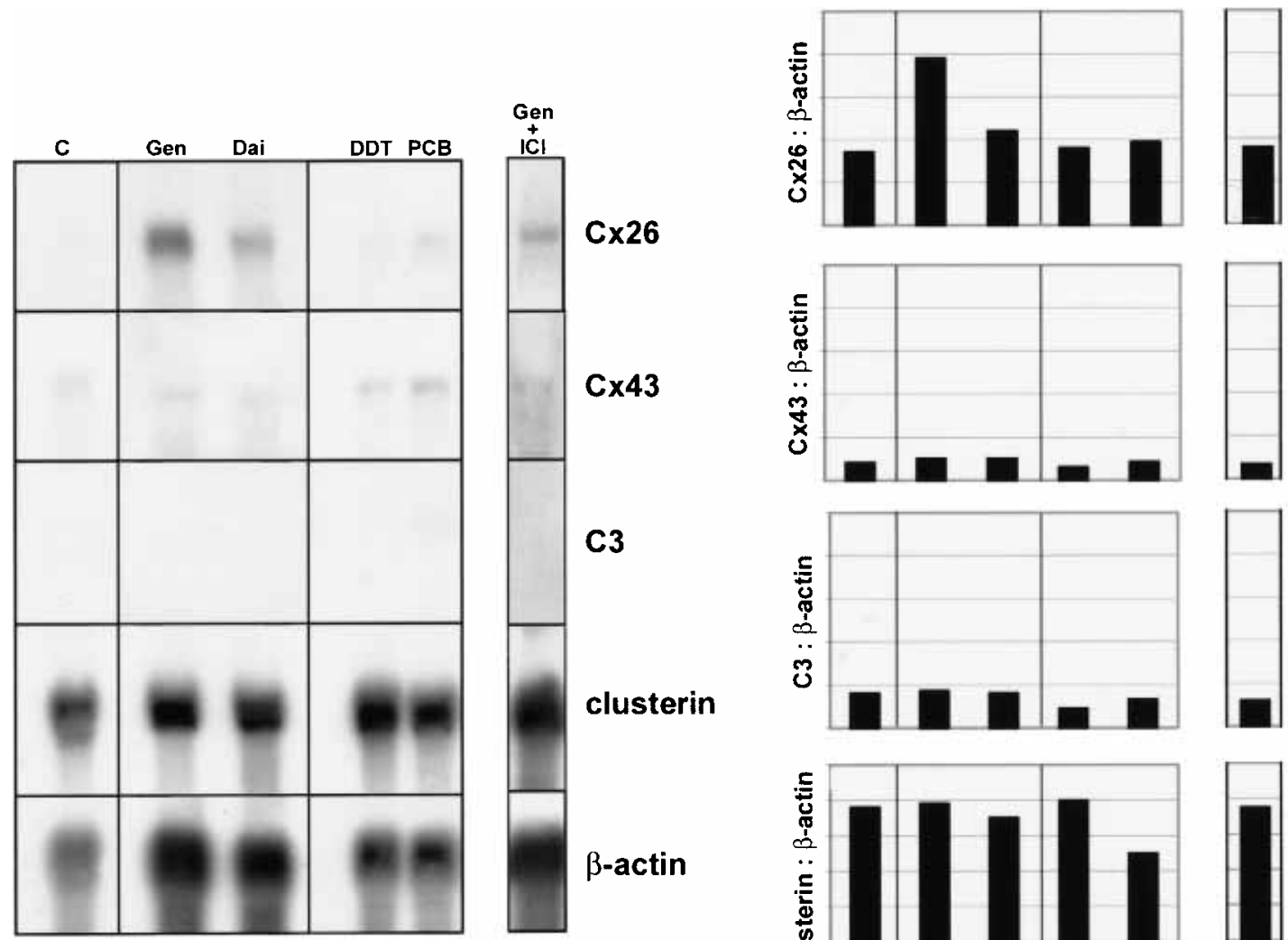

\section{Cx26}

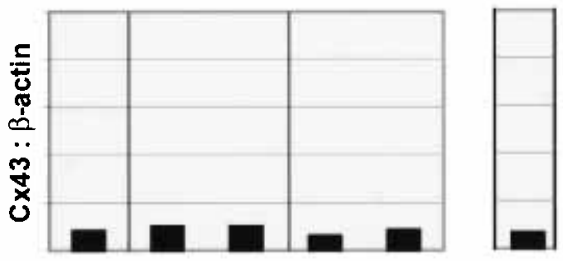

C3

Cx43

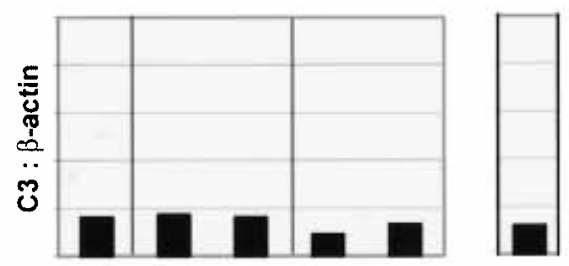

clusterin

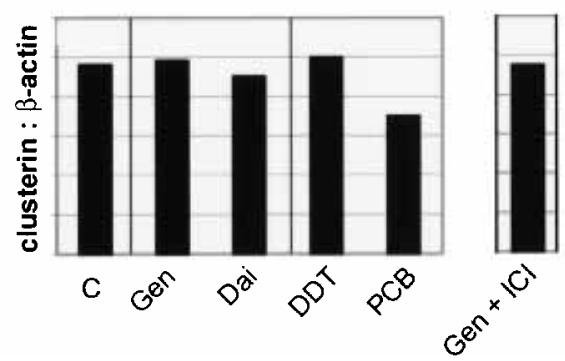

Figure 4 Northern blot (left) and corresponding densitometric evaluation (right) of rat endometrial RNA. Application of the phytoestrogen genistein leads to induction only of Cx26 gene expression, which can be inhibited by simultaneous application of $0.5 \mathrm{mg} \mathrm{ICI} 182,780$ (ICI). The amount of custerin transcript expression is reduced $24 \mathrm{~h}$ after injection of PCB. Daidzein and DDT have no clear effect on endometrial gene expression $24 \mathrm{~h}$ after application. Controls $(\mathrm{C})$ were treated with vehicle only.

The estrogenic effect of tamoxifen and raloxifen also acts via the estrogen receptor, as it could be inhibited by application of the antiestrogen ICI 182,780 (Fig. 3). Interestingly, the amount of clusterin transcripts was clearly enhanced by simultaneous application of $0.5 \mathrm{mg}$ ICI 182,780 compared with untreated ovariectomized rats. This phenomenon was also observed after application of DES and ICI 182,780 (compare Fig. 1 with Fig. 3).

\section{Regulation of gene expression by phytoestrogens and industrial compounds}

A single subcutanous injection of $2.5 \mathrm{mg}$ of the phytoestrogen genistein led to an increase in Cx26 gene expression within $24 \mathrm{~h}$. This induction could be suppressed by simultaneous application of the antiestrogen ICI 182,780. However, at this concentration genistein caused no effect with regard to the amounts of $\mathrm{Cx} 43, \mathrm{C} 3$ and clusterin gene transcripts (Fig. 4). In constrast to genistein, a single application of $2.5 \mathrm{mg}$ of the phytohormone daidzein revealed no visible effect on either of the endometrial genes tested $24 \mathrm{~h}$ after subcutaneous injection (Fig. 4).

The industrial compound DDT at a concentration of $2.5 \mathrm{mg} / \mathrm{rat}$ had no effect on the endometrial genes tested, whereas $24 \mathrm{~h}$ after the application of the xenoestrogen PCB, a slight reduction of clusterin mRNA could be observed (Fig. 4). 


\section{Discussion}

To obtain more comprehensive information about the estrogenic activity of natural and synthetic estrogens we tested short-term regulation of the estrogen responsive genes $\mathrm{Cx} 26, \mathrm{Cx} 43, \mathrm{C} 3$ and clusterin in rat endometrium. Estrogen agonists, as well as the SERMs tamoxifen and raloxifen, demonstrated a similar effect on regulation of Cx26, C3 and clusterin gene transcription, and the three genes showed comparable sensitivity to these compounds. Previous studies revealed that Cx26 is regulated sensitively by estrogen (Grümmer \& Winterhager 1998, Grümmer et al. 1999). Here, we confirm this responsiveness to even lower estrogen concentrations as well as to SERMs and phytoestrogens. $\mathrm{Cx} 43$, which is known to be regulated by estrogen at higher concentrations (Grümmer et al. 1999), is obviously less sensitive to estrogens, and its expression was not modulated by the conditions used in the present study. Differences with regard to transcriptional regulation of endometrial genes, however, were observed after application of phytoand xenoestrogens. Thus the gene cluster analysis in response to different estrogenic stimuli revealed that different signaling pathways may be involved.

In general, the most sensitive regulation of gene expression was obtained by application of $17 \beta$ estradiol. The strong $\mathrm{E}_{2}$ agonist DES, which reveals an even higher binding capacity to the estrogen receptor (ER) than $\mathrm{E}_{2}$ (Kuiper et al. 1997), had less effect on Cx26, C3 and clusterin gene transcription than comparable concentrations of estradiol. Thus the physiological effect of DES seems to be less than could have been expected from ER binding assays. This confirms the observation of other groups that estrogen receptor binding assays do not allow conclusions to be drawn regarding the biological activity of estrogenic substances (Hopert et al. 1998, Strunck et al. 2000), and that hormonal activity can only be evaluated in a biological model.

Selective estrogen receptor modulators (SERMs) act either as ER agonists or antagonists, dependent on the target tissue. The synthetic estrogen, tamoxifen, which is widely used as an antiestrogen in the treatment of breast cancer (Nass et al. 1998, Overmoyer 1999) reveals agonistic effects in the uterus which lead to an increased risk of development of endometrial cancer after long-term tamoxifen therapy (Assikis \& Jordan 1995, Sato et al. 1996, Carmichael 1998). We confirmed this agonistic effect on the endometrium by its influence on transcriptional regulation of $\mathrm{Cx} 26, \mathrm{C} 3$ and clusterin gene expression.

Considerable effort has been made to identify compounds which lack unwanted agonistic effects. The related substance raloxifen, which also acts as an estrogen antagonist in breast tissue (Jordan 1998) does not stimulate endometrial proliferation. Corresponding to the studies of Sato and coworkers (1996) who showed a slight agonistic effect in the uterus, raloxifen also reveals weak estrogenic effects in rat endometrium with regard to regulation of the reference genes Cx26, C3 and clusterin. The effects of these antiestrogens are mediated by the estrogen receptor as shown in this and other publications (Grese et al. 1997, Paech et al. 1997). However, the molecular mechanisms for gene- and tissue-specific effects of selective estrogen receptor modulators are not known in detail.

Recently, a novel ER subtype (ERbeta) was discovered by Kuiper and coworkers (1996). The two ER subtypes, alpha and beta, are expressed differentially in estrogen target tissues (Kuiper et al. 1997). It is supposed that the tissue-specific effects of SERMs correspond to the tissue distribution of the different estrogen receptor subtypes. It could be shown that tamoxifen is a potent transcriptional activator with ERbeta via an AP1 site, whereas estradiol inhibits transcription after binding to ERbeta, but activates transcription with ERalpha (Paech et al. 1997). In addition, different expression of transcriptional coactivators and corepressors which modulate receptor activity may result in tissue-specific activation of certain genes (Horwitz et al. 1996, McKenna \& O’Malley 2000).

Much less is known about the regulatory effects of phytoestrogens on gene expression patterns in vivo. Phytoestrogens constitute a diverse group of plant-derived compounds possessing estrogenic activity (Strauss et al. 1998a) and revealing multiple biological effects, including beneficial effects on osteoporosis, breast cancer, prostate cancer and menopausal symptoms (Adlerkreutz \& Mazur 1997, Barnes 1998, Clarkson et al. 1998), and on the cardiovascular system (St Clair 1998). On the other hand, epidemiological and experimental studies suggest that the consumption of a phytoestrogen-rich diet may decrease the risk of estrogen-related cancers such as breast and prostate 
cancer (Adlerkreutz 1995, Strauss et al. 1998a). However, the causal relationship as well as the mechanisms of action still remain to be demonstrated, and there is only sparse evidence of an antiestrogenic effect of phytoestrogens (Mäkelä et al. 1994, Ruh et al. 1995). Phytoestrogens bind to both types of ER, induce estrogen-responsive genes and their action can be blocked by antiestrogens (Mäkelä et al. 1994, Kuiper et al. 1997). However, most of the phytoestrogens bind to the estrogen receptor with a lower affinity than $17 \beta$-estradiol (Kuiper et al. 1997) and are weakly estrogenic in vitro (Markiewicz et al. 1993) and in vivo (Diel et al. 2000). The single largest source of phytoestrogens in the human diet is from soy or soy products. Consumption of soy has been shown to lengthen the menstrual cycle (Phipps et al. 1993, Cassidy et al. 1994), and animal studies suggest that soy protein is able to prevent cardiovascular diseases (Anthony et al. 1996) but may also cause severe reproductive tract disorders including impaired fertility (Burroughs et al. 1990, Strauss et al. 1998b) which could be explained by the estrogenic activity of phytoestrogens. Here, we have shown that the soy isoflavonoid genistein exclusively increases $\mathrm{Cx} 26$ gene expression in rat endometrium via the ER, but at the concentration used in this study it had no effect on transcription of the C3 and clusterin genes which, however, revealed a similar sensitivity to estrogen as Cx26. This indicates a specific signaling pathway for genistein action. It is known that genistein is a specific inhibitor of protein tyrosine kinases (Akiyama et al. 1987) and thus may interfere with the regulation of certain endometrial genes. It has to be taken into consideration that sesame oil, a natural plant oil which has been used as a vehicle in this study, might itself reveal estrogenic effects (Markaverich et al. 2002). However, controls which have included injecting sesame oil as vehicle revealed no induction of the target gene products, showing that the influence of sesame oil is negligible in this study.

Involvement of different estrogen receptor cofactors as well as estrogen receptor subtypes has to be considered when investigating the estrogenic activity of natural and synthetic estrogens (Kuiper et al. 1998). Although the biological role of ERbeta is poorly understood, the relative binding affinity of specific estrogens to ERbeta and ERalpha varies widely. This could, in addition to the recruitment of different subsets of coactivator or corepressor complexes, provide a mechanism by which SERMs as well as environmental estrogens reveal tissue selective actions. To evaluate the role of the different ER subtypes, experiments with ERalpha and ERbeta knockout mice have to be performed.

In contrast to our results, Hopert and coworkers (1998) showed in an in vitro assay using established rat endometrial adenocarcinoma cells that genistein and daidzein increased formation of complement C3. The uterotropic activity of daidzein has previously been described as low (Farmakalidis et al. 1985). Our results indicate that genistein reveals a higher short-term estrogenic potency in vivo than its inactive analog daidzein. However, daidzein has been shown to be capable of regulating clusterin and C3 mRNA expression in the rat uterus after 3 days application via a gastric tube (Diel et al. 2000).

The industrial compound DDT had no visible effect on endometrial gene transcription within $24 \mathrm{~h}$ of application. In previous studies, it had proved to be a potent estrogen as regards the uterotropic response and the regulation of progesterone receptor and clusterin gene expression (Diel et al. 2000). In contrast to the present study, however, in those experiments DDT had been applied orally and for a longer time period. Polychlorinated biphenyls (PCBs) belong to the most widespread industrial products in the ecosystem, giving rise to serious environmental contamination, and are a potential hazard to health. It was shown in previous studies that they possess the ability to mimic estrogen action mediated through estrogen receptors (Nesaretnam et al. 1996); this was confirmed in the present study as they revealed an estrogenic effect by suppressing clusterin gene expression.

In agreement with the results of Diel and coworkers (2000) we have demonstrated that alteration of the expression of specific uterine genes is a more estrogen-sensitive parameter than, for example, increase in uterine weight. In addition, we have shown that the endometrial genes Cx26 and clusterin are at least as sensitive parameters as C3 and thus are highly suited to investigate the biological potential of natural and synthetic estrogens. An estrogen responsive element which promotes a direct effect of the activated ER on the promotor has been identified only for the C3 
gene (Vik et al. 1991). The signal cascades involved are still unknown and may vary for different genes with similar sensitivity to estrogenic compounds.

Investigating gene expression of tissues from exposed animals offers the possibility to assay for induction of genes that are regulated by still unknown signaling pathways and it ensures that effects derived both from the tested compound and from its metabolites are detected.

The endometrium is one of the main target tissues for estrogenic effects. The present study reveals that analysis of clusters of estrogen-sensitive endometrial genes could help to identify compounds revealing estrogenic potency, assess their biological activity, and elucidate the involvement of different signal cascades. In addition, endocrine disruptors which could interfere with the physiological differentiation state of the endometrium could be identified by cDNA arrays composed of these genes as a simple approach for screening conspicuous substances.

\section{Acknowledgements}

The authors thank Dr Alan Wakeling (Zeneca Pharmaceuticals, UK) for providing ICI 182,780, $\mathrm{G}$ Vollmer for providing cDNA probes for C3 and clusterin, and M Rajewsky for stimulating these experiments. We thank Gabriele Luhn and Georgia Rauter for excellent technical assistance and Dave Kittel for the preparation of the Figures.

\section{References}

Adlercreutz H 1995 Phytoestrogens: epidemiology and a possible role in cancer. Environmental Health Perspectives 103 (Suppl 7) $103-112$.

Adlercreutz H \& Mazur W 1997 Phyto-oestrogens and Western diseases. Annals in Medicine 29 95-120.

Akiyama T, Ishida J, Nakagawa S, Ogawara H, Watanabe S, Itoh N, Shibuya M \& Fukami Y 1987 Genistein, a specific inhibitor of tyrosine-specific protein kinases. Fournal of Biological Chemistry 262 $5592-5595$.

Anthony MS, Clarkson TB, Hughes CL, Morgan TM \& Burke G 1996 Soybean isoflavones improve cardiovascular risk factors without affecting the reproductive system of peripubertal rhesus monkeys. Fournal of Nutrition 126 43-50.

Assikis VJ \& Jordan VC 1995 Gynecologic effects of tamoxifen and the association with endometrial carcinoma. International fournal of Gynaecology and Obstetrics 49 241-257.
Auger J, Czyglik F, Kunstmann JM, Czyglik F \& Jouannet P 1995 Decline in semen quality among fertile men in Paris during the past 20 years. New England Fournal of Medicine 332 281-285.

Barnes S 1998 The chemopreventive properties of soy isoflavonoids in animal models of breast cancer. Breast Cancer Research and Treatment 46 169-179.

Beyer EC, Paul DL \& Goodenough DA 1987 Connexin43: a protein from rat heart homologous to a gap junction protein from liver. Fournal of Cell Biology 105 2621-2629.

Burroughs CD, Mills KT \& Bern HA 1990 Long-term genital tract changes in female mice treated neonatally with coumestrol. Reproductive Toxicology 4 127-135.

Carmichael PL 1998 Mechanisms of action of antiestrogens: relevance to clinical benefits and risks. Cancer Investigation 16 604-611.

Cassidy A, Bingham S \& Setchell KD 1994 Biological effects of a diet of soy protein rich in isoflavones on the menstrual cycle of premenopausal women. American fournal of Clinical Nutrition $\mathbf{6 0}$ 333-340.

Clarkson TB, Anthony MS, Williams JK, Honore EK \& Cline JM 1998 The potential of soybean phytoestrogens for postmenopausal hormone replacement therapy. Proceedings of the Society of Experimental Biology and Medicine 217 365-368.

Cooper RL \& Kavlock RJ 1997 Endocrine disruptors and reproductive development: a weight of evidence overview. Fournal of Endocrinology 152 159-166.

Cotton D 1994 Environmental estrogenic agents: area of concern. Fournal of the American Medical Association 271414416.

Davis DL, Bradlow HL, Wolff M, Woodruff T, Hoel DG \& Anton-Culver H 1993 Medical hypothesis: xenoestrogens as preventable causes of breast cancer. Environmental Health Perspectives $101372-377$.

Diel P, Schulz T, Smolnikar K, Strunck E, Vollmer G \& Michna H 2000 Ability of xeno- and phytoestrogens to modulate expression of estrogen-sensitive genes in rat uterus: estrogenicity profiles and uterotropic activity. Fournal of Steroid Biochemistry and Molecular Biology 73 1-10.

Farmakalidis E, Hathcock JN \& Murphy PA 1985 Oestrogenic potency of genistin and daidzin in mice. Food and Chemical Toxicology 23 741-745.

Grese TA, Sluka JP, Bryant HU, Cullinan GJ, Glasebrook AL, Jones CD, Matsumoto K, Palkowitz AD, Sato M, Termine JD, Winter MA, Yang NN \& Dodge JA 1997 Molecular determinants of tissue selectivity in estrogen receptor modulators. PNAS 94 14105-14110.

Grümmer R \& Winterhager E 1998 Regulation of cx26 and cx43 transcripts in rat endometrium by progesterone and $17 \beta$-estradiol. European Fournal of Cell Biology 75 (Suppl. 48) 26.

Grümmer R, Chwalisz K, Mulholland J, Traub O \& Winterhager E 1994 Regulation of connexin26 and connexin43 expression in rat endometrium by ovarian steroid hormones. Biology of Reproduction 51 1109-1116.

Grümmer R, Traub O \& Winterhager E 1999 Gap junction connexin genes cx26 and cx43 are differentially regulated by ovarian steroid hormones in rat endometrium. Endocrinology 140 2509-2516.

Guenette RS, Corbeil HB, Leger J, Wong K, Mezl V, Mooibroek M \& Tenniswood M 1994 Induction of gene expression during involution of the lactating mammary gland of the rat. Fournal of Molecular Endocrinology 12 47-60.

Hopert AC, Beyer A, Frank K, Strunck E, Wunsche W \& Vollmer G 1998 Characterization of estrogenicity of phytoestrogens in an endometrial-derived experimental model. Environmental Health Perspectives 106 581-586.

Horwitz KB, Jackson TA, Bain DL, Richer JK, Takimoto GS \& Tung L 1996 Nuclear receptor coactivators and corepressors. Molecular Endocrinology 10 1167-1177. 
Jordan VC 1998 Molecular biology of the estrogen receptor aids in the understanding of tamoxifen resistance and breast cancer prevention with raloxifene. Recent Results in Cancer Research 152 265-276.

Jorgensen M, Hummel R, Bevort M, Andersson AM, Skakkebaek NE \& Leffers H 1998 Detection of oestrogenic chemicals by assaying the expression level of oestrogen regulated genes. APMIS $106245-251$.

Kuiper GGJM, Enmark E, Pelto-Huikko M, Nilsson S \& Gustafsson JA 1996 Cloning of a novel receptor expressed in rat prostate and ovary. PNAS 93 5925-5930.

Kuiper GGJM, Carlsson B, Grandien K, Enmark E, Haggblad J, Nilsson S \& Gustafsson JA 1997 Comparison of the ligand binding specifity and transcript tissue distribution of estrogen receptors alpha and beta. Endocrinology 138 863-870.

Kuiper GG, Lemmen JG, Carlsson B, Corton JC, Safe SH, van der Saag PT, van der Burg B \& Gustafsson JA 1998 Interaction of estrogenic chemicals and phytoestrogens with estrogen receptor beta. Endocrinology $1394252-4263$.

Lan NC \& Katzenellenbogen BS 1976 Temporal relationships between hormone receptor binding and biological responses in the uterus: studies with short- and long-acting derivatives of estriol. Endocrinology 98 220-227.

McKenna NJ \& O'Malley BW 2000 From ligand to response: generating diversity in nuclear receptor coregulator function. Fournal of Steroid Biochemistry and Molecular Biology 74 351-356.

Mäkelä S, Davis VL, Tally WC, Korkman J, Salo L, Vihko R, Santti R \& Korach KS 1994 Dietary estrogens act through estrogen receptor-mediated processes and show no antiestrogenicity in cultured breast cancer cells. Environmental Health Perspectives $102572-578$.

Markaverich B, Mani S, Alejandro MA, Mitchell A, Markaverich D, Brown T, Velez-Trippe C, Murchison C, O'Malley B \& Faith R 2002 A novel endocrine-disrupting agent in corn with mitogenic activity in human breast and prostatic cancer cells. Environmental Health Perspectives 110 169-177.

Markiewicz L, Garey J, Adlerkreuz H \& Gurpide E 1993 In vitro bioassays of nonsteroidal phytoestrogens. Foumal of Steroid Biochemistry and Molecular Biology 45 399-405.

Nass SJ, Hahm HA \& Davidson NE 1998 Breast cancer biology blossoms in the clinic. Nature Medicine 4 761-762.

Nesaretnam K, Corcoran D, Dils RR \& Darbre P 1996 3,4,3', 4' Tetrachlorobiphenyl acts as an estrogen in vitro and in vivo. Molecular Endocrinology 10 923-936.

Overmoyer BA 1999 The breast cancer prevention trial (P-1 study). The role of tamoxifen in preventing breast cancer. Cleve Clinical Fournal of Medicine 66 33-40.

Paech K, Webb P, Kuiper GGJM, Nilsson S, Gustafsson J, Kushner PJ \& Scanlan TS 1997 Differential ligand activation of estrogen receptors ERalpha and ERbeta at APl sites. Science $\mathbf{2 7 7}$ 1508-1510.

Phipps WR, Martini MC, Lampe JW, Slavin JL \& Kurzer MS 1993 Effect of flax seed ingestion on the menstrual cycle. Fournal of Clinical Endocrinology and Metabolism 77 1215-1219.

Reuss B, Hellmann P, Dahl E, Traub O, Butterweck A, Grummer R \& Winterhager E 1996 Connexins and E-cadherin are differentially expressed during trophoblast invasion and placenta differentiation in the rat. Developmental Dynamics 205 172-182.

Ruh MF, Zacharewski T, Connor K, Howell J, Chen I \& Safe S 1995 Naringenin: a weakly estrogenic bioflavonoid that exhibits antiestrogenic activity. Biochemical Pharmacology 50 1485-1493.
Safe SH 1995 Environmental and dietary estrogens and human health: is there a problem? Environmental Health Perspectives 103 346-351.

Sato M, Rippy MK \& Bryant HU 1996 Raloxifene, tamoxifen, nafoxidine, or estrogen effects on reproductive and nonreproductive tissues in ovariectomized rats. FASEB fournal $\mathbf{1 0}$ 905-912.

Schaefer WR, Zahradnik HP \& Frijus P 1996 Anthropogene Substanzen mit unerwünschter Östrogenwirkung. Umweltmedizin 1 $35-42$.

Sharpe RM \& Skakkebaek NE 1993 Are oestrogens involved in falling sperm count and disorders of the male reproductive tract? The Lancet 341 1392-1395.

St Clair RW 1998 Estrogens and atherosclerosis: phytoestrogens and selective estrogen receptor modulators. Current Opinion in Lipidology 9 457-463.

Strauss L, Santti R, Saarinen N, Streng T, Joshi S \& Makela S $1998 a$ Dietary phytoestrogens and their role in hormonally dependent disease. Toxicology Letters 102-103 349-354.

Strauss L, Makela S, Joshi S, Huhtaniemi I \& Santti R 1998 b Genistein exerts estrogen-like effects in male mouse reproductive tract. Molecular and Cellular Endocrinology 144 83-93.

Strunck E, Stemmann N, Hopert A, Wunsche W, Frank K \& Vollmer G 2000 Relative binding affinity does not predict biological response to xenoestrogens in rat endometrial adenocarcinoma cells. Fournal of Steroid Biochemistry and Molecular Biology 74 73-81.

Sundstrom SA, Komm BS, Ponce-de-Leon H, Yi Z, Teuscher C \& Lyttle CR 1989 Estrogen regulation of tissue-specific expression of complement C3. Fournal of Biological Chemistry 264 16941-16947.

Thierfelder W, Mehnert WH \& Laugmann D 1995 Der Einfluß umweltrelevanter östrogener oder östrogenartiger Substanzen auf das Reproduktionssystem. Bundesgesundheitsblatt 9 338-341.

Traub O, Look J, Dermietzel R, Brummer F, Hulser D \& Willecke K 1989 Comparative characterization of the $21-\mathrm{kD}$ and $26-\mathrm{kD}$ gap junction proteins in murine liver and cultured hepatocytes. Fournal of Cell Biology 108 1039-1051.

Traub O, Willecke K, Breuer I \& Stachewsky M 1992 Changes in expression of three different connexins in organs and tissue during mouse embryonic development. European Fournal of Cell Biology 57 36-81.

Vik DP, Amiguet P, Moffat GJ, Fey M, Amiguet-Barras F, Wetsel RA \& Tack BF 1991 Structural features of the human C3 gene: intron/exon organization, transcriptional start site, and promoter region sequence. Biochemistry 30 1080-1085.

Winterhager E, Stutenkemper R, Traub O, Beyer E \& Willecke K 1991 Expression of different connexin genes in rat uterus during decidualization and at term. European fournal of Cell Biology $\mathbf{5 5}$ 133-142.

Wunsche W, Tenniswood MP, Schneider MR \& Vollmer G 1998 Estrogenic regulation of clusterin mRNA in normal and malignant endometrial tissue. International Fournal of Cancer 76 684-688.

Zacharewski T 1997 In vitro bioassays for assessing estrogenic substances. Environmental Science Technology 31 613-623.

Zhang JT \& Nicholson B 1989 Sequence and tissue distribution of a second protein of hepatic gap junctions, cx26, as deduced from its cDNA. Fournal of Cell Biology 109 3391-3401.

Received 25 April 2002 Accepted 20 May 2002 